\title{
Analysis and Evaluation of Public-Private Partnership Development in The Field of Historical and Cultural Heritage Sites Preservation in the Regions of Russia
}

\author{
Ekaterina A. Eremeeva ${ }^{1}$, Tatiana V. Khalilova ${ }^{2}$, Ludmila S. Leontieva ${ }^{3}$, Regina Ye. Yurtayeva ${ }^{4}$ \\ 1, 2, 3, ${ }_{4}$ Kazan Federal University, Institute for Management, Economics and Finance \\ Email: thalilova2004@mail.ru, anka2007901@mail.ru, Contact: +79600577146
}

Received: 21st October 2017 Accepted: 16th November 2017, Published: 31st December 2017

\begin{abstract}
This article is devoted to the application of publicprivate partnership (PPP) mechanisms in the field of historical and cultural monument preservation in Russian Federation. Today, the mechanisms of publicprivate partnership become the fundamental tool for the development of regional and municipal infrastructure, the attraction of investments, and the quality of services improvement provided to the population. The mechanisms of interaction between a state and business can be used in different spheres of the economy. Their implementation in the social sphere is the most relevant, including the field of cultural and historical heritage object preservation, which, on the one hand, need to be restored and protected, and on the other hand, they can generate income. Based on the system approach and the methodological recommendations of the Ministry of economic development of Russia, the article analyzes and assesses the level of public-private partnership development in the field of historical and cultural heritage site preservation in the regions of the Volga Federal District of Russia. They performed the analysis of the conditions created in each of the studied regions for the implementation of public-private partnerships, regulatory framework, etc. Based on the results of the analysis, the problem areas were revealed for the implementation of public-private partnership projects, the recommendations were proposed to improve the mechanisms of public-private partnership in relation to the objects of historical and cultural heritage.
\end{abstract}

Keywords: Objects of Historical and Cultural Heritage, Interaction between State and Business, Public-Private Partnership, Public-Private Partnership in the field of Historical and Cultural Heritage Site Preservation.

\section{Introduction}

The objects of cultural heritage in modern conditions become an important factor in regional socialeconomic development. All this necessitates their saving, guarding and restoring. However, the regional mechanism of monument management that has been formed to the present day does not meet the objectives of cultural heritage object preservation and the maximizing of their involvement in economic turnover fully. An effective solution of preservation, functioning and maintenance of historical and cultural heritage objects of Russia can be ensured by the involvement of these objects in economic and cultural circulation through the use of public-private partnerships (PPPs). In the scientific literature, the study of public-private partnership in the field of historical and cultural heritage conservation has different perspectives of analysis. First of all, these are the works devoted to the substantiation of the interrelation between economy and culture, traditions and social innovations [1, 2, 3]; to the study of actual mechanisms of the state influence on the processes of the cultural heritage preservation $[4,5,6]$. During the analysis of this topic, the authors also relied on the theoretical studies of modern institutional forms of PPPs [7, 8, 9, 10, 11, 12], contributing to the decrease of corruption-related nature of state-civil interactions in the process of cultural heritage object use [13]. Statistical calculations are based on scientific and methodological developments of experts from the Ministry of Economic Development of Russian Federation and the Center for PPP development, who conduct a comprehensive assessment of public-private partnership development level in the regions of Russia [14].

\section{Methods}

The work is based on the method of the system approach, which allows to study the relationship between state and private business and determine the prospects for their development. The calculation of RF subject indicators on the level of public-private partnership development was carried out in accordance with the methodology of the Ministry of economic development of Russia. The value of the integral indicator of each region was determined on the basis of such factor value assessment as:

- The experience of PPP projects implementation in Russian Federation;

- Regulatory and legal support for PPP in RF subject;

- The development of RF subject institutional environment in the sphere of PPP.

The indicator of a region was determined on the basis of data provided by Rosstat and the subjects of Russia.

\section{Results and Discussion}

The Volga Federal District (VFD) includes 14 regions. The cultural and historical heritage of these regions has a significant development potential. There are more than 17,600 objects of cultural heritage of federal, 
Helix Vol. 8(1): 2499- 2505

regional and municipal significance on the territory of

the district (Figure 1).

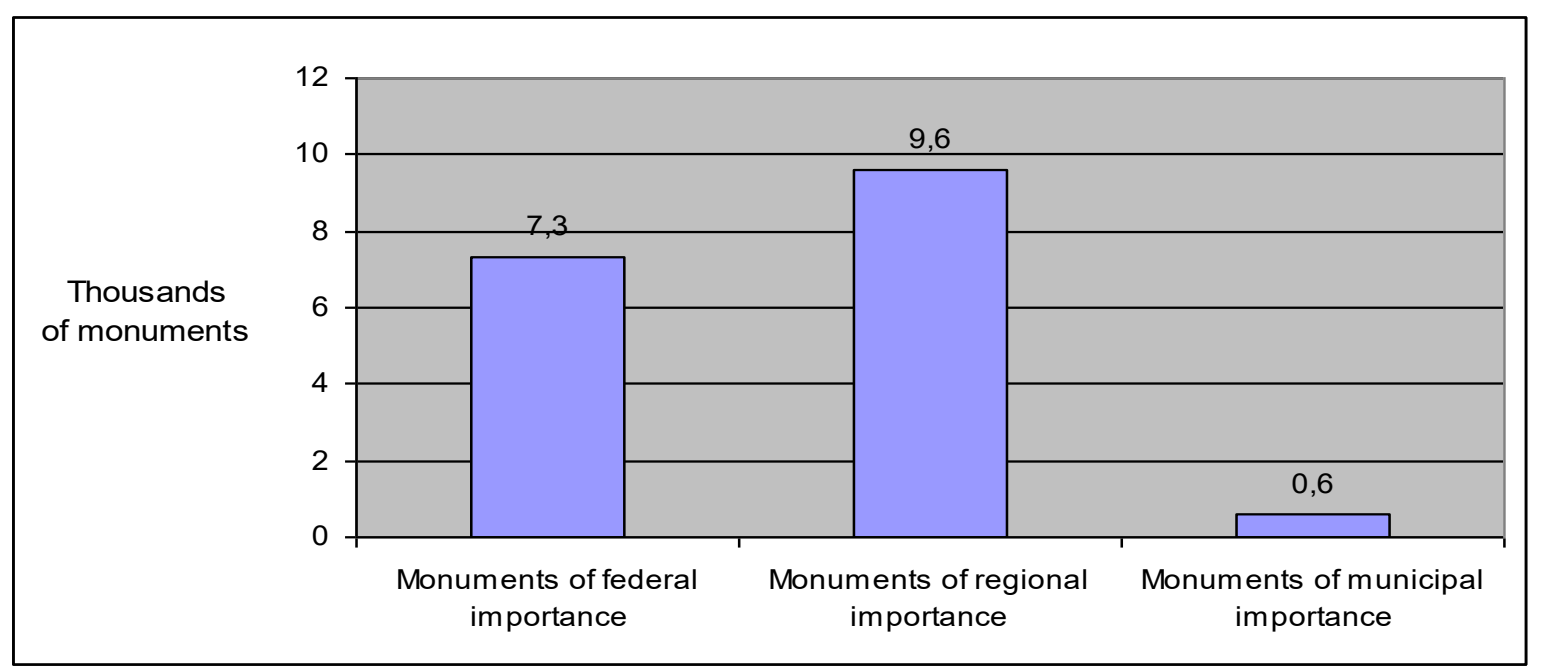

Fig. 1. Objects of VFD Cultural Heritage by forms of Ownership

As can be seen from Table 1, the largest number of objects of archaeological and cultural heritage is in Nizhny Novgorod region, the Republic of Tatarstan and Perm region. The least number of monuments of culture is located in Kirov, Penza regions and in the Udmurt Republic.

Table 1. Number of Objects of Archaeological and Cultural Heritage in the Regions of the Volga Federal District

\begin{tabular}{|l|c|}
\hline \multicolumn{1}{|c|}{ Region } & Objects of archaeological and / or cultural heritage (units) \\
\hline Nizhny Novgorod Region & 4467 \\
\hline The Republic of Mordovia & 855 \\
\hline Chuvash Republic & 674 \\
\hline Republic of Mari El & 1059 \\
\hline Republic of Tatarstan & 1757 \\
\hline Ulyanovsk region & 1087 \\
\hline Samara region & 703 \\
\hline Penza region & 371 \\
\hline Saratov region & 4179 \\
\hline Perm region & 2944 \\
\hline Udmurt republic & 304 \\
\hline Republic of Bashkortostan & 1891 \\
\hline Kirov region & 839 \\
\hline Orenburg region & 1769 \\
\hline
\end{tabular}

However, it should be noted that most of cultural heritage objects need to carry out the works on conservation and restoration today, as evidenced by the data in Table 2. 
Helix Vol. 8(1): 2499- 2505

Table 2. Summary Table on the Technical Condition of Cultural Heritage Objects of VFD Regions

\begin{tabular}{|l|l|l|}
\hline \multirow{2}{*}{ VFD region } & Emergency state & \multicolumn{2}{l|}{} \\
\cline { 2 - 3 } & Amount & \multicolumn{2}{l|}{} \\
\hline Republic of Bashkortostan & 43 & 7,7 \\
\hline Kirov region & 28 & 3,8 \\
\hline Mari El Republic & 51 & 24,3 \\
\hline The Republic of Mordovia & 15 & 14,3 \\
\hline Nizhny Novgorod Region & 42 & 1,3 \\
\hline Orenburg region & 32 & 14,1 \\
\hline Penza region & 31 & 12,6 \\
\hline Perm region & 27 & 5,3 \\
\hline Samara region & 28 & 5,8 \\
\hline Saratov region & 73 & 11,0 \\
\hline Republic of Tatarstan & 34 & 3,0 \\
\hline Udmurt republic & 38 & 6,8 \\
\hline Ulyanovsk region & 80 & 4,3 \\
\hline Chuvash Republic & 41 & 10,2 \\
\hline
\end{tabular}

Among the problems of historical and cultural heritage site preservation in VFD regions, the most significant are the following ones:

- the lack of financial resources in the sphere of culture; - the lack of effective mechanisms to involve private funds in the cultural sphere;

- the lack of resources and qualified personnel necessary to carry out restoration work on cultural monuments, etc.

The solution of the abovementioned problems can be the development of public-private partnership mechanisms in the sphere of cultural heritage preservation. At the moment the application of PPP mechanism is just started within this area in Russia. Currently, only 873 PPP projects are being implemented in Russia, for which the corresponding agreements have been concluded (more than 1300 projects in total at various stages of implementation) with the total volume of private investments of 640.3 billion rubles at the stage of infrastructure facility creation (construction / reconstruction).

In order to assess the level of public-private partnership development in the field of historical and cultural heritage preservation in the subjects of the Volga Federal District, we will analyze the rating of regions by the level of PPP development in 2015-2016, based on the analysis of several indicators, the first of which is the experience in the implementation of PPP projects.

It can be noted that only 10 subjects of the VFD implementing public-private partnership projects in the field of cultural heritage preservation, in four subjects of the VFD - the Republics of Mordovia and Udmurtia, Perm Krai and Penza region have no such projects. At the same time, most of these projects are the restoration of cultural and historical heritage objects, their restoration and adaptation to modern use. The main sources of PPP project financing are private investments and regional budgets. The projects are implemented on the basis of concession agreements.

The next indicator for the analysis of PPP development level in the regions is the availability of an appropriate regulatory and legal framework. All regions of the Volga federal district, except for the Republic of Mari $\mathrm{El}$, have a relevant law on public-private partnership. In Mari El Republic, a corresponding Decree of the Republic of Mari El government was adopted. The normative legal acts adopted in VFD regions approve the procedure for the interaction of authorities in the development and the review of PPP projects, the procedure for a tender organization concerning the right to conclude an agreement on PPP and other issues. 
Helix Vol. 8(1): 2499- 2505

Leading rating positions on the factor "Regulatory base" are occupied by the Ulyanovsk region and the Republic of Bashkortostan. In Russia in general, these regions occupy the second and the ninth place, respectively. The outsiders of the rating are the Republic of Udmurtia and Perm region. The evaluation of the "regulatory base" factor indicators in the regions of the Volga Federal District is presented in Table 3.

Table 3. Estimation of "Regulatory base" Factor Indicators in VFD Regions

\begin{tabular}{|c|c|c|c|c|c|c|}
\hline Region & 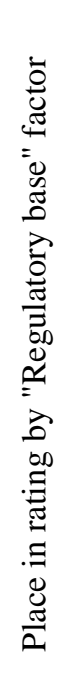 & 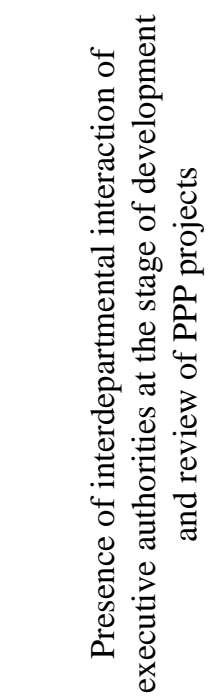 & 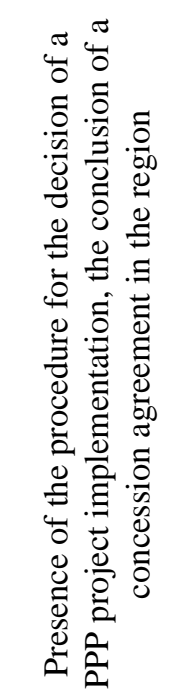 & 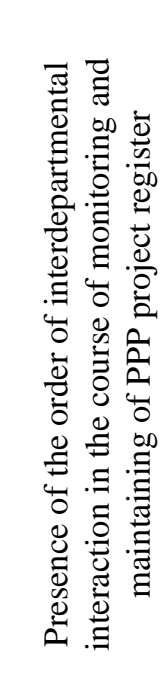 & 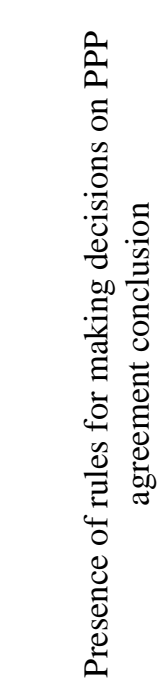 & 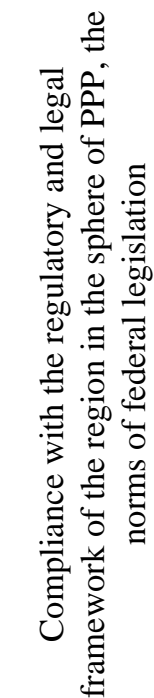 \\
\hline 1 & 2 & 3 & 4 & 5 & 6 & 7 \\
\hline $\begin{array}{l}\text { Republic of } \\
\text { Bashkortostan }\end{array}$ & 9 & + & + & - & - & + \\
\hline Mari El Republic & 19 & - & + & - & - & + \\
\hline $\begin{array}{l}\text { The Republic of } \\
\text { Mordovia }\end{array}$ & 51 & - & - & - & - & + \\
\hline $\begin{array}{l}\text { Republic of } \\
\text { Tatarstan }\end{array}$ & 38 & - & + & - & - & + \\
\hline Kirov region & 41 & - & + & - & - & + \\
\hline $\begin{array}{l}\text { Nizhny Novgorod } \\
\text { Region }\end{array}$ & 32 & - & + & - & - & + \\
\hline Orenburg region & 17 & - & + & + & - & + \\
\hline Penza region & 33 & & + & - & - & + \\
\hline Perm Region & 57 & + & - & - & - & - \\
\hline Samara Region & 21 & + & + & + & + & + \\
\hline Saratov region & 25 & + & + & + & + & + \\
\hline Chuvash Republic & 42 & - & + & - & - & + \\
\hline Udmurt republic & 62 & + & + & - & - & - \\
\hline Ulyanovsk region & 2 & + & + & + & + & + \\
\hline
\end{tabular}


Nowadays, such issues, as the preparation and the implementation of concession projects, the interdepartmental cooperation during the initiation, the preliminary coordination and the development of concession projects on the initiative of the executive authorities, including the development of the list of objects for which concession agreements are planned, need normative consolidation; the control, the supervision, the monitoring and the maintenance of PPP project register, etc.

The next indicator of PPP development in Russian Federation regions is the development of the institutional environment. In order to assess this factor, they analyzed the presence of an authorized body, the number of experts who received special training, the availability of an open access list of facilities for which it is planned to conclude PPP agreements, concession agreements, etc.

As of April 1, 2017, six regions of the Volga Federal District - Tatarstan, Bashkortostan, Nizhny Novgorod, Samara and Ulyanovsk regions, in Perm Krai - have authorized regional authorities responsible for the development of PPP. Some regions of VFD adopted investment memorandums, the programs or strategies that regard public-private partnership as the mechanism for private funds attraction. In the Republics of Tatarstan, Bashkiria, Chuvashia, in Nizhny Novgorod,
Samara and Ulyanovsk regions, in Perm Krai, the list of facilities for which PPP agreements are planned is compiled and submitted to the public. Besides, in these regions, government officials have special qualifications in the field of PPP project management. In some VFD subjects, such as the Republic of Mordovia, the Republic of Udmurtia, Penza, Kirov and Saratov regions, the state of the institutional environment can be assessed as unsatisfactory. This has a negative impact on the prospects of investment attraction in PPP projects.

We will calculate the achievements of KPI and the place of VFD regions in 2015-2016. The symbols used in the calculations are the following ones:

$\mathrm{F}$ - the final integral indicator of RF subject in 2015;

KPI - the established value of the indicator concerning the level of PPP development in RF subject for 2015;

The achievement of KPI is the difference between the final rating value and the set value for 2015;

$\mathrm{P}$ - the place by "project implementation experience" factor;

$\mathrm{H}$ - the place by "regulatory base" factor;

Inst. - the place by "Institutional environment" factor.

The achievement of KPI and the places of VFD regions concerning each of the factors for rating calculation in the sphere of the cultural and historical heritage preservation are presented in Table 4.

Table 4. Achievement of KPI and VFD Region Places for each of Rating Calculation Factors in 2015/2016

\begin{tabular}{|l|l|l|l|l|l|l|}
\hline VFD region & F & KPI & KPI achievement & P & H & Inst. \\
\hline $\begin{array}{l}\text { Republic of } \\
\text { Bashkortostan }\end{array}$ & $41,2 \%$ & $40,2 \%$ & $1,0 \%$ & 17 & 9 & 18 \\
\hline Mari El Republic & $9,6 \%$ & $21,0 \%$ & $-11,4 \%$ & 46 & 19 & 22 \\
\hline $\begin{array}{l}\text { The Republic of } \\
\text { Mordovia }\end{array}$ & $22,4 \%$ & $22,4 \%$ & $0,0 \%$ & 53 & 51 & 64 \\
\hline $\begin{array}{l}\text { Republic of } \\
\text { Tatarstan }\end{array}$ & $43,0 \%$ & $52,0 \%$ & $-9,0 \%$ & 7 & 38 & 16 \\
\hline $\begin{array}{l}\text { Kirov region } \\
\text { Nizhny Novgorod } \\
\text { region }\end{array}$ & $53,6 \%$ & $55,0 \%$ & $-1,4 \%$ & 53 & 41 & 53 \\
\hline Orenburg region & $30,7 \%$ & $29,6 \%$ & $1,1 \%$ & 3 & 32 & 6 \\
\hline Penza region & $19,9 \%$ & $21,5 \%$ & $-1,6 \%$ & 27 & 17 & 40 \\
\hline Perm region & $31,5 \%$ & $39,6 \%$ & $-8,1 \%$ & 56 & 33 & 38 \\
\hline Samara region & $59,6 \%$ & $48,5 \%$ & $11,1 \%$ & 9 & 57 & 52 \\
\hline Saratov region & $28,2 \%$ & $26,6 \%$ & $1,6 \%$ & 26 & 25 & 48 \\
\hline Chuvash republic & $26,6 \%$ & $32,5 \%$ & $-5,9 \%$ & 35 & 42 & 21 \\
\hline
\end{tabular}


Helix Vol. 8(1): 2499- 2505

\begin{tabular}{|l|l|l|l|l|l|l|}
\hline Udmurt republic & $40,0 \%$ & $37,3 \%$ & $2,7 \%$ & 10 & 62 & 14 \\
\hline Ulyanovsk region & $44,6 \%$ & $37,5 \%$ & $7,1 \%$ & 23 & 2 & 12 \\
\hline
\end{tabular}

Based on the calculation results, subjects can be divided into 4 groups:

- the regions with a high level of PPP development $45-60 \%$ - are referred to Samara and Nizhny Novgorod regions;

- the regions with an average level of PPP development - 35-45\% - Ulyanovsk region, Republics of Tatarstan, Bashkortostan and Udmurtia;

- the regions with a low level of PPP development - 25$35 \%$ - Perm Krai, Orenburg and Saratov regions, Chuvash republic and the Republic of Mordovia;

- to regions with very low level of PPP development $0-25 \%$ - Penza and Kirov regions, as well as the Republic of Mari El.

As can be seen from Table 4, the Samara region occupies the highest position in the Volga Federal District. The value of the actual indicator concerning the level of PPP development in Samara region exceeded the established level by $11.1 \%$. Now there are 74 projects in this area at various stages of implementation, the main part of which is focused on the development of social infrastructure. The total volume of private investments in these projects amounted to 11.8 billion rubles. At the same time, budgetary funds are not used in the implementation of these PPP projects.

The category of regions with an average level of PPP development in the area of historical and cultural heritage object preservation is represented by 4 VFD regions. Public-private partnership in these regions is at a fairly high level. Ulyanovsk region is the leader of this category of subjects. Next comes the Republic of Tatarstan, the territory of which implements a large number of municipal concessions in the social sphere and the projects of the cultural sector. It can be noted that the regions of this group unite such a feature as the creation of understandable conditions for investors to implement PPP projects.

The regions in which PPP are in the process of development are among the group with a low level of PPP development. The lagging position of these regions can be explained by a low level of their investment attractiveness.

The latter group includes the regions with very low level of PPP development, in which there is almost no experience of public-private partnership mechanism application in the sphere of culture. The institutional environment of these regions is not prepared for the implementation of PPP projects in this area.

\section{Summary}

Based on the analysis, we can say that the successful use of the PPP mechanism in the field of cultural monuments preservation in Russian Federation requires the following:
1. The development of legislation at the regional level and Russia in general, taking into account the norms of international law;

2. Control improvement concerning terms and PPP project costs through the creation of independent centers of expertise;

3. The creation of a single information center that would accumulate experience and knowledge regarding the implementation of PPP projects;

4. The stimulation of the authority interest in the implementation of PPP projects. With regard to the activities of executive bodies, it is necessary:

- to determine the procedure of cultural heritage object selection taking into account public opinion;

- to determine a number of indicators for the protection of cultural heritage sites to assess the effectiveness of the executive heads from the authorities of Russian Federation subjects;

5. Financial incentives for PPP projects by fixing a preferential tax rate on property and a lower rent for the use of PPP object or a land plot.

6 . The development of nationwide monitoring system concerning the state of cultural heritage sites and their use.

The implementation of these proposals will preserve the monuments of cultural and historical heritage, and will also involve them in economic turnover by private investment attraction for their preservation and the development of tourism and business activity in the area of their location.

\section{Acknowledgements}

The work is performed according to the Russian Government Program of Competitive Growth of Kazan Federal University.

\section{References}

[1] Trosby D. (2013). Economics and culture: translation from English. Moscow: the publishing house of the Higher School of Economics. 256 p.

[2] Landry Ch. (2011). Creative City: translation from English. - M.: Publishing house "Classics XXI". $399 \mathrm{p}$.

[3] Sibirtseva Yu. A., Kildyashova T.A. (2011). Cultural resources of the territory: the development strategy // The Bulletin of Northern (Arctic) federal university. Series: humanities and social sciences. No2. pp. 120-124.

[4] Hodge G.A., Greve C. (2007) Public-private partnerships: an international performance review. Public Adm. Rev., 67(3), pp. 545-558.

[5] T. de Vries (2007) Ambiguity in an Alaskan History Theme Park: Presenting "History as Commodity" and "History as Heritage". The Public Historian, 29 (2), pp. 55-79. 
[6] Kalimullina I.R. (2013) Modernization of cultural object protection methods / I.R. Kalimullina. Kazan, 150 p.

[7] Webb R. \& Pulle B. (2002) Public private partnerships: An introduction. Canberra: Commonwealth of Australia. Research paper no. 1 (3) [8] Adams, J., Young, A., \& Wu, Z. (2006). Public private partnerships in China: System, constraints and future prospects. International Journal of Public Sector Management, 19(4), 384-396.

[9] J. Edelenbos, G.R. Teisman (2008) Publicprivate partnership: on the edge of project and process management. Insights from Dutch practice: the Sijtwende spatial development project. Environ. Plan. C Gov. Policy, 26 (3), p. 614.

[10] M. Wang (2013) Public-private partnerships in China Public Administration Review, 73 (2), pp. 311-312.

[11] Chizhevskaya E., Magomaeva L. (2015) Economic Prospects for Public-Private Partnership in Russia and European Union. Asian Social Science, 11 ( 2).

[12] Zakharova E.N., Mokrushin A.A., Pshizova A.R., Khatukay S.A., Chinazirova S.K. (2015) Forms and Mechanisms of Public-Private Partnerships in Innovative Modernization of the Western Europe Economies. Asian Social Science, 11(21).

[13] Leontieva L.S., Khalilova T.V., Gaynullina L.F. \& Khalilov A.I. (2015) Social-Communciative Innovations in Anti-Corruption Activities. Asian Social Science, 11 (7).

[14] The development of public-private partnership in Russia during 2015-2016. The rating of regions by the level of PPP development (2016) / Association "PPP development center", Ministry of Economic Development of Russian Federation. - Moscow: The association "Center for PPP development". 36 p. 